\title{
SS-063 反すう研究の最前線一国内で行われた研究を中心に一
}

\author{
企画代表者, 話題提供者, 司会者：長谷川 晃 (東海学院大学) \\ 話题提供者: 西村 春輝 (筑波大学) \\ 話題提供者: 國里 愛彦 (専修大学) \\ 指定討論者: 大平 英樹 (名古屋大学)
}

反すうは抑うつ・うつ病と密接に関わる思考パターンである。世界的に見て, 反すうに関する文献は 過去10年間で暴発的に増加し, 近年では臨床心理学のみならず, 認知心理学, 脳科学, 行動遺伝学といっ た異なる分野の理論や手法が用いられて研究が行われている。反すう研究が世界中で行われているとい うことは, 当分野の発展に扔いて喜ばしい状況であるが, 日本の研究者が新規参入をしにくい状況であ るということも否めない。本シンポジウムでは国内で行われている反すう研究について紹介し, その理 論的示唆について議論しつつ, 国内の研究者が当分野の発展に貢献する道筋についても考えたい。まず, 長谷川が社会的問題解決と衝動性の観点から, 西村氏が実行機能の観点から, 国里氏が脳画像の観点か ら話題提供を行う。その上で, 感情心理学に関する幅広い研究に取り組み, 国際誌に多くの著書を掲載 している大平氏にご討論頂き, 議論を深めたい。

一第2 日 9 月23日(水) $15: 30 \sim 17: 30$

\section{SS-064 心理学と言語教育科学の連携に向けて一理解と産出・コミュニ ケーションの観点からー}

\author{
企画代表者，指定討論者，司会者：宇佐美まゆみ（東京外国語大学） \\ 話題提供者：野田 尚史\#（国立国語研究所） \\ 話題提供者: 迫田久美子\#（国立国語研究所） \\ 話题提供者: 福田 由紀 (法政大学) \\ 話題提供者: 小川 一美 (愛知淑徳大学) \\ 指定討論者:森島 泰則 (国際基督教大学)
}

\begin{abstract}
心理学の分野では, 学習, 言語心理学, 教育心理学, 社会心理学など, 言語教育に深く関係する分野 があり, 研究も盛んである。一方, 心理学の方法論を引継ぎながらも, その興味を第二言語習得に特化 して発展してきた第二言語習得論は, 今では日本語や英語の個別言語や言語学の背景を持つ研究者が中 心となって独自に研究を進めている。そのため, ベースとなる分野の興味の主眼や方法論, 研究発表の 場の違い等によって, 互いの研究に有意義な視点や共有すべき重要な研究課題が, 有機的に連携して発 展してきているとは言い難い。そこで, 心理学をべースとし長年言語教育科学にかかわってきた企画者 が, 両分野の有機的連携の契機を作るべく, 両分野の研究者に言語に関する最新の研究について話題提 供していただき, それを基に, 両分野の指定討論者が, 具体的な課題や協働の糸口, 両分野の相互発展 の方向性について論じる。その後, フロアも交えて皆で一緒に考えたい。
\end{abstract}

